\title{
Legislative Purpose, Rationality, and Equal Protection
}

Under the rubric of the Equal Protection Clause, the Supreme Court has repeatedly held that statutory schemes may treat classes of citizens differently only if the statutory classifications are rationally related to the purpose of the statute. ${ }^{1}$

The Equal Protection Clause ... imposes a requirement of some rationality in the nature of the class singled out. To be sure, the constitutional demand is not a demand that a statute necessarily apply equally to all persons. "The Constitution does not require things which are different in fact ... to be treated in law as though they were the same." . . But the Equal Protection Clause does require that, in defining a class subject to legislation, the distinctions that are drawn have "some relevance to the purpose for which the classification is made."

In recent years, when the Court has determined that a "fundamental interest" 3 or a "suspect classification" 4 is involved, it has buttressed the basic requirement of "some rationality" with the additional requirements that the government show a higher degree of rationality as well

I. E.g. Eisenstadt v. Baird, 405 U.S. 438 (1972); Recd v. Reed, 404 U.S. 71 (1971): Dandridge v. Williams, 397 U.S. 471 (1970); McDonald v. Bd. of Election Comm'rs. 394 U.S. 802 (1969); Williamson v. Lee Optical Co., 348 U.S. 483 (1953); Tigner v. Texas, 310 U.S. 141 (1940); Smith v. Cahoon, 283 U.S. 553 (1931); FS. Royster Guano Co. v. Virginia, 253 U.S. 412 (1920); Miller v. Wilson, 236 U.S. 373 (1915); Lindsley v. Natural Car. bonic Gas Co., 220 U.S. 61 (1911); Gulf Colo. \& Santa Fe Ry. v. Ellis, 16J US. 150 (1897). Cf. Levy v. Louisiana, 391 U.S. 68 (1968); Carrington v. Rash. 380 U.S. 89 (1965); Skinner v. Oklahoma, 316 U.S. 535 (1942); Yick Wo v. Hopkins, 118 U.S. 356 (1886).

2. Rinaldi v. Yeager, 384 U.S. 305, 308 (1966) (citations omitted).

3. The principal characteristic of a "fundamental interest" appcars to be that the Court calls the interest fundamental. The right to procreate was termed "One of the basic civil rights of man" in Skinner v. Oklahoma, 316 U.S. 535, 541 (1942). But, while conceding that the right to a minimal income involved the "most basic economic needs of impoverished human beings." that right has not been treated as fundamental. See Dandridge v. Williams, 397 U.S. $471,484-85$ (1970). For examples of interests held to be fundamental, see Shapiro v. Thompson, 394 U.S. 618 (1969) (right to travel); Harper v. Virginia Bd. of Elections, 383 U.S. 663 (1966) (right to votc); Carrington v. Rash. 380 U.S. 89 (1965) (right to vote); Reynolds v. Sims, 377 U.S. 533 (196-1) (right to vote). See generally Note, Developments in the Law-Equal Protection, 82 Hanv. L. REv. 105j (1969).

4. Suspect classifications have been described as groups which are in special need of protection because they are "discrete and insular" minorities. United States v. Carolenc Products Co., 304 U.S. 144, 152-53 (1938). See, e.g., Graham v. Richardson, 403 US. 365 (1971) (nationality); Williams v. Rhodes, 393 U.S. 23 (1968) (political allegience); Harper v. Virginia Bd. of Elections, 383 U.S. 663 (1966) (wealth); Korematsu v. Unitcd States, 323 U.S. 214 (1944) (race). Cf. Levy v. Louisiana, 391 U.S. 68 (1968) (illegitimac). See Tussman and tenBroek, The Equal Protection of the Lau's, 37 CALIf. L. REv. 341, 35664 (1949). 
as a compelling interest to justify the statute. Emphasis on these newer doctrines diverted attention from analysis of the function of the traditional minimal equal protection standard.' Very recently, however, the Court has displayed increasing reliance on the "some rationality" test again. It has used the traditional test to sustain a maximum welfare grant rule, ${ }^{7}$ to strike down a statute under which men were preferred to women as administrators of decedents' estates, ${ }^{8}$ and to void a law that made it illegal for unmarried persons to obtain contraceptives. ${ }^{9}$ This renewed emphasis on the traditional rationality requirement and the partial dependence of the fundamental interest and suspect category doctrines on the basic idea of rationality ${ }^{10}$ highlight the need to clarify conceptual problems underlying the rationality test.

Much analysis of the rationality requirement has centered on the issue of classificatory accuracy. ${ }^{11}$ Courts and commentators have asked whether a statute's classifications include individuals who are irrelevant to the statutory purpose or whether they exclude those who are relevant to that purpose. ${ }^{12}$ But the question of whether a statute's classifications are precisely related to its purpose does not depend only on the nature of the classifications; it depends also on how the purpose of the statute is defined. ${ }^{13}$. An examination of the plurality opinion in Eisenstadt $v$. Baird, ${ }^{14}$ for example, suggests that the decisive question is how courts formulate the legislative purpose against which the rationality of the statutory classification is to be tested.

In Baird the Supreme Court struck down ${ }^{15}$ a Massachusetts statute

5. See, e.g., Shapiro v. Thompson, 394 U.S. 618, 634 (1969). ("But in moving from State to State ... appellees were exercising a constitutional right, and any classification which serves to penalize the exercise of that right, unless shown to be nccessary to promote a compelling governmental interest, is unconstitutional.") The fact that the classification used must be "necessary to promote a compelling governmental in. terest" appears to mean that the Court will examine the statute's classificatory accuracy with more care. See id. at 631-38; note 114 infra.

6. But see Ely, Legislative and Administrative Motivation in Constitutional Latw, 79 YALE L.J. 1205 (1970) [hereinafter cited as Ely].

7. Dandridge v. Williams, 397 U.S. 471,485 (1970).

8. Reed v. Reed, 404 U.S. 71,76 (1971).

9. Eisenstadt v. Baird, 405 U.S. $438,446.47$ (1972).

10. Both doctrines apparently require not only a compelling governmental interest but also a higher degree of classificatory accuracy to justify a statute which burdens a fundamental interest or suspect category. See note 5 supra. The requirement that such a statute's classifications be accurate with respect to the purpose of the statute is simply an alternative formulation of the rationality requirement. Se't pp. 146.49 infra.

11. There seems to be an axiom to fit any degree of accuracy the courts might wish to require. See Skinner v. Oklahoma, 316 U.S. 535, 540.41 (1942).

12. See, e.g., Tussman and tenBroek, supra note 4 , at 343.53 .

13. See Ely, supra note 6, at 1224-28, 1237-49. See generally pp. $132-38$ infra.

14. 405 U.S. 438 (1972).

15. Only Chief Justice Berger dissented from the Court's action. The plurality opin. ion by Justice Brennan, voiding the statute on equal protection grounds, drew the 
that, inter alia, made it a crime for anyone to dispense contraceptives to unmarried persons for the purpose of preventing pregnancy. ${ }^{10}$ The statute permitted physicians and pharmacists to dispense contraceptives to married persons for the purpose of preventing pregnancy, and it had been construed to permit anyone to dispense contraceptives to married or unmarried persons for the purpose of preventing disease. ${ }^{17}$ Justice Brennan's plurality opinion tested this statutory scheme against the "some rationality" test, which he formulated in traditional terms:

The Equal Protection Clause ... does ... deny to States the power to legislate that different treatment be accorded to persons placed by a statute into different classes on the basis of criteria wholly unrelated to the objective of that statute. ${ }^{15}$

The specific question posed by the plurality opinion, therefore, was "whether there is some ground of difference that rationally explains the different treatment accorded married and unmarried persons under [the Massachusetts statute]."19 The plurality determined that the statute was not rationally related to any of the three possible legislative objectives considered. ${ }^{20}$

The first legislative goal considered was the discouragement of premarital sexual activity. The plurality found that the statute had "at best a marginal relation" to this objective because under the statute unmarried persons could obtain contraceptives if they were to be used for the prevention of disease. ${ }^{21}$ It was also observed that the statute could not prevent married persons from obtaining contraceptives in order to engage in sexual activity with unmarried persons. ${ }^{22}$ Thus,

support of Justices Marshall and Stewart. Justice Douglas concurred on a First Amend. ment rationale. Justice White, joined by Justice Blackmun, concurred on the ground that the statute was overly broad because it required a medical preseription to obtain vaginal foam. Justices Powell and Rehnquist did not participatc.

16. MASS. GEN. LAws ch. 272 (1968) provides in relevant part:

$\$ 21$ Except as provided in section twenty-one $A$, whoever selts, lends, gives away. exhibits . . any drug, medicine, instrument or article whatever for the prevention of conception or for causing unlawful abortion, or manufactures or makes any such article shall be punished ....

$\$ 21$ (A) A registered physician may administer to or preseribe for any married person drugs or articles intended for the prevention of pregnancy or conception. $A$ registered pharmacist actually engaged in the business of pharmacy may furnish such drugs or articles to any married person presenting a preseription from a registered physician.

17. See Commonwealth v. Corbett, 307 Mrass. 7, 8-14 (1910).

18. 405 U.S. at 447 (quoting Reed v. Reed, 404 U.S. $71,75.76$ (1971)).

19. 405 U.S. at 447 .

20. The plurality apparently determined which legislative objectives to consider by examining the terms of the statute and by noting what objectives Massachusetts courts had previously attributed to the statute. Id.

21. Id. at 448 .

22. Id. at 449 . 
because the statute would eliminate only an insignificant amount of premarital sexual activity, the plurality opinion declared that it could not have been rationally intended to discourage such activity. ${ }^{23}$

The plurality opinion then held the statute not rationally related to the second objective considered: that of regulating the distribution of potentially harmful drugs and devices. The plurality argued that if "there is a need to have a physician prescribe ... contraceptives, that need is as great for unmarried persons as for married persons."24 That is, because physicians were not permitted by the statute to prescribe contraceptives to unmarried persons for the prevention of pregnancy, that whole class of persons was excluded from the benign regulatory scheme. Since physicians are presumably as skillful in protecting the health of the unmarried as they are of the married, the plurality concluded that the exclusion of the unmarried from medical supervision indicated that the statute was not rationally related to the goal of regulating the distribution of potentially harmful drugs. ${ }^{25}$

Finally, the plurality found that the statute was not rationally related to the third objective considered, preventing the use of contraceptives, because the terms of the statute did not forbid their use by married persons. ${ }^{26}$

By treating each legislative objective separately, the plurality opinion achieved apparent analytic clarity, but the isolated consideration of each objective was misleading in at least two ways. It enabled the plurality to use statutory terms, which in fact made the statute quite reasonable in relation to one purpose, as evidence that the statute was not rational in relation to a different and irrelevant purpose. For example, consider how the plurality argued that the distinction drawn by the statute between married and unmarried persons was not rational in relation to the public health objective of regulating the distribution of potentially harmful drugs. ${ }^{27}$ This distinction was drawn, obviously, because the statute was also designed to discourage in some degree premarital sexual activity by making most kinds of contracep.

23. Id. at 450 .

24. Id.

25. Id. In his dissent Justice Burger properly questioned the plurality's reasoning on this point. "Assuming the legislature too broadly restricted the class of persons whio could obtain contraceptives, it hardly follows that it saw no need to protect the health of all persons to whom they are made available." $1 d$. at 468 . But see id. at 451, n.8. The plurality opinion also relied the argument made in a concurrence that the statute was over-broad with regard to this public health objective because too many types of contraceptives were included. Id. at 451, n.9.

26. Id. at 454 .

27. See note 25 supra. 
tives harder to get for the unmarried..$^{28}$ It is not surprising that the distinction had no clear relationship to another, quite different purpose of the statute, that of seeing that those who could legally get contraceptives got medical supervision as well. If the two purposes are considered together, the distinction between married and unmarried persons is not irrational in relation to the public health objectiveit is merely irrelevant.

The "divide and conquer" analytical tactic also permitted a convenient simplification of each purpose, for it is only in the context of the full statutory scheme that full meaning can be given to each legislative objective. For example, when the plurality opinion discussed the third objective (preventing the general use of contraceptives), it asserted that the evil "as perceived by the State" was identical as between the use of contraceptives by married and by unmarried people. ${ }^{29}$ The plurality could then argue that exemption of married persons from the prohibition against obtaining a prescription was not rational, for if contraception itself is evil, is it not as evil for married as for unmarried persons? But, if the legislation was also designed to discourage premarital sexual activity, the use of contraceptives by unmarried persons manifestly is not the same evil as is their use by married persons. ${ }^{30}$

These illustrations show that if the plurality had defined the overall legislative purpose as consisting of the partial achievement of several sub-purposes, the determination that the statute was not rational would not have been so easy. The legislature's overall purpose might have been defined as follows: to discourage premarital sex by making contraceptives harder to obtain to the extent that this would not increase the risks of venereal disease; to provide for the medical supervision of the distribution of contraceptives to the extent that this would not increase the availability of contraceptives to the unmarried; and to discourage the use of contraceptives to the extent that this would not interfere with the private behavior of married persons. Unless it is "irrational" per se for a legislature to design a statute to achieve a set

28. The statute was contained in a chapter relating to "Crimes Against Chastity. Morality, Decency, and Good Order." Id. at 450.

29. Id. at 454 .

30. A legislator might, for example, believe that the use of contraceptives is an evil, although a necessary evil in the case of married couples, since cren in Massachusetts, people who are married are expected to engage in some sexual activity. The same legislator might also believe that restricting the availability of contracepiives to un. married persons would discourage the evil of pre-marital sexual activity and somewhat abate the evil of general use of contraceptives. 
of somewhat conflicting policy objectives, the Massachusetts statute would appear to have been rational.

The more systematic discussion of the relationship between "purpose" and "rationality" which follows will show that the inadequacies in the Baird plurality's use of legislative "purpose" are by no means unique to that case. Although the results it produces may be commendable on other grounds, the traditional equal protection rationality test applied in these cases is invariably an empty requirement and a misleading analytic device.

\section{Rationality and the Definition of Purpose}

It is always possible to define the legislative purpose of a statute in such a way that the statutory classification is rationally related to it. When a statute names a class, that class must share some common characteristic for that is the definitional attribute of a "class." ${ }^{11}$ The nature of the burdens or benefits created by a statute and the nature of the chosen class's commonality will always suggest a statutory purpose-to so burden or benefit the common trait shared by members of the identified class. A statute's classifications will be rationally related to such a purpose because the reach of the purpose has been derived from the classifications themselves. ${ }^{32}$ Legislative purpose so defined is nearly tautological but it is also the purpose suggested by the plain terms of a statute. For deciding whether "the distinctions that are drawn [by the statute] have 'some relevance to the purpose for which the classification is made" "33 the purpose suggested by the terms of a statute serves as well as any other. ${ }^{34}$

31. Cf. Tussman and tenBroek, supra note 4, at 344-45.

32. Professor Ely has previously posited the same concept:

A decision to aid artists rather than oilmen is defensible in terms of promoting the arts; punishing battery more harshly than burglary is defensible in terms of the safeguarding of physical security. And so is any such choice thus defensible, because courts are prepared to credit as acceptable any goal the political branches view as contributing to the general welfare. Thus each choice will import its own goal ... and the requirement of a "rational" choice-goal relation will be satisfied by the very making of the choice.

Ely, supra note 6, at 1247. The same idea is also noted in passing in Note, Develop. ments in the Law-Equal Protection, supra note 3, at 1082. See also Tussman and tenBroek, supra note 4 , at 351 .

33. P. 123 supra. Compare the Baird plurality's formulation of the rationality test at p. 125 supra.

34. There are, of course, other possible sources for ascertaining legislative purpose. It is possible to look to the legislative history to see what the legislators said they intended to accomplish; one can look at political circumstances, etc., to see what thcy actually intended or at the actual impact of a statute. Finally, one can look at a combination of these factors along with the statutory terms themselves. Leaving aside 
The process of deriving a legislative purpose (and substantiating its rationality) from any statute's terms can be illustrated by an examination of the statute at issue in Magoun v. Illinois Trust and Savings Bank. $^{35}$ That statute was an inheritance tax which distinguished between classes of beneficiaries in two ways. First, the rate of taxation varied according to the closeness of the blood relationship. Second, among legatees who were unrelated by blood to the deceased, the rate varied according to the amount received (but not proportionately). The nature of the burden-a tax-suggests one possible purpose:

(1) The purpose is to reduce but not eliminate inherited wealth. The difference in tax rate according to the closeness of the blood tie suggests another purpose:

(2) The purpose is to encourage gifts to near relatives.

the question of whether any of these alternative sources of legislative purpose are empirically determinable (see pp. 141-42 infra for the analogous problem with ascertaining motivation), which of these possible purposes is the "real" purpose which must be utilized in the equal protection rationality test? The question has never been answered, perhaps because of the empirical problem.

If it were argued, however, that some other source (as jet undefined) of legislative purpose must be employed in the rationality test, an entirely new doctrine vould be invoked. Since the "tautological" purpose of a statute, suggested by its terms, always exists, requiring the use of some other legislative purpose can only be justified on the basis that its importance (for whatever reason) outweighs that of the purpose suggested by a statute's terms. But such explicit balancing of legislative purposes has never been required by the Court as a pre-condition to the rationality test nor would it be the traditional rationality requirement itself. See pp. $146-49$ infra.

The terms of a statute, then, while not the only source for determining legislative purpose, are $a$ source and the purpose they suggest is a purpose to which the statutory classifications may be compared to implement the rationality requirement of the Equal Protection Clause.

35. 170 U.S. 283 (1898). The statute provided:

[A]ll property, real, personal and mixed which shall pass by will or by the intestate laws of this State... shall be ... subject to a tax at the rate hercinafter specified .... When ... property or income therefrom shall pass to or for the use of any father, mother, husband, wife, child, brother, sister, wife or widow of the son or the husband of the daughter, or any ... children adopted ... in every such case the rate of tax shall be one dollar on cvery hundred dollars. . . . When the ... property or income there from shall pass to or for the use of any uncle, aunt, niece, nephew or any lineal descendant of the same, in crery such case the rate of such tax shall be two dollars on every one hundred dollars. . . . In all other cases the rate shall be as follows: on each and every hundred dollars ... on all estates of ten thousand dollars and less, three dollars; on all $\infty$ tates of over ten thousand dollars and not exceeding twenty thousand dollars, four dollars; on all estates over twenty thousand dollars and not exceeding fifty thousand dollars, five dollars; and on all estates over fifty thousand dollars, six dollars.

IrL. REV. STAT. ch. 120 (1895).

Magoun is unusual among Equal Protection cases in that the Court did not apply the rationality test as it is normally formulated. The Court inquired only whether there was "some difference which bears a just and proper relation to the attempted classification." 170 U.S. at 294 (quoting Gulf, Colo. \& Santa Fe Ry. v. Ellis, 165 U.S. $150,165(1897)$ ) (emphasis added). That is, the Court asked whether there were dif. ferences among the classes treated differently under the terms of the statute but did not ask whether those differences were related to any statutory purpose. Cf. Tussman and tenBroek, supra note 4 , at 346 . 
As to this second purpose, the statutory classification is over-inclusive since an individual without near relatives is taxed despite the fact that he cannot be encouraged to leave his wealth to near relatives. Identification of this imprecision only suggests a refinement of the statement of purpose:

(3) The purpose is to reduce transfer of wealth through inheritance but to do so to the extent compatible with encouraging intrafamilial support. If the statutory purpose is seen as a mix of sub-purposes, the classifications can be accurate as to the overall purpose-thereby satisfying the "some rationality" test-while inaccurate as to a sub-purpose. The identification of an imprecision (a finding of non-rationality) only means that the purpose of the statute has not yet been fully stated. The third and more fully stated purpose in the example is more complete because it more accurately reflects the statutory terms. To say that the purpose of the statute is to discourage inheritance but to do so to a lesser degree when the wealth would go to support near relatives is merely to restate the statutory terms that provide for a tax on inheritance but a lower tax on a legacy to a near relative. The Court considered such a process of increasingly refined speculation unnecessary in Magoun; instead it merely pointed to differences among the statutory classes and upheld the statute. ${ }^{36}$

Considered together, the majority and dissenting opinions in Levy v. Louisian $a^{37}$ do go through precisely this process of speculation as to legislative purpose. The statute considered in Levy created a right to sue for wrongful death of a mother; it gave such a right to legitimate children but withheld the right from illegitimate children. ${ }^{88}$ The nature of the benefit given suggests one purpose:

(1) The purpose is to compensate children for the loss of their mother resulting from wrongful death.

Justice Douglas saw no difference between the two sets of children in relation to this purpose:

36. 170 U.S. 283 at 294.

37. 391 U.S. 68 (1968).

38. The right to recover ... if the injured person dies, shall survive for a period of one year from the death of the deceased in favor of: (1) the surviving spouse and child or children of the deceased ...; (2) the surviving father and mother of the deceased .. . if he left no spouse or child surviving; and (3) the surviving brothers and sisters of the deceased ... if he left no spousc, child, or parent surviving . . . .

As used in this article, the words "child," "brother," "sister," "father," and "mother" include a child, brother, sister, father, and mother, by adoption, respectively.

LA. Civ. Code ANN. art. 2315 (Supp. 1967). "Child" has been construed to mean "legiti. mate child." Levy v. State, 193 So. 2d 193, 195 (Ct. App. La. 1967). 
These children, though illegitimate, were dependent on her; she cared for them and nurtured them; they were indeed hers in the biological and in the spiritual sense; in her death they suffered wrong in the sense that any dependent would. ${ }^{30}$

But the statutory classification suggests that compensation for loss was not the only purpose of the statute. Noting that the statute had been construed to distinguish between legitimate and illegitimate children, ${ }^{40}$ Justice Harlan argued:

If it be conceded, as I assume it is, that the State has power to provide that people who choose to live together should go through the formalities of marriage ... it is logical to enforce these requirements by declaring that the general class of rights that are dependent upon family relationships shall be accorded only when the formalities ... of those relationships are present. ${ }^{41}$

Thus, the classificatory distinctions suggest a second purpose:

(2) The purpose is to encourage the formalization of relationships between parents.

Justice Douglas was surely right that the statute is under-inclusive with respect to the first purpose since some children who suffered the wrong of their mother's death would not be compensated. But it is not underinclusive with respect to a fuller statement of the purpose:

(3) The purpose is to compensate children for the wrongful death of their mother to the extent that such compensation does not legitimize relationships that have never been legally formalized.

The restatement of statutory terms in Magoun and Levy as statutory purposes is not intended to prove that the statutory terms will suggest all of the legislation's purposes. But if a burden or a benefit is placed on a group that shares a trait that can be named, at least one purpose for doing so can always be to burden or benefit those that share the trait. To be sure, it might be an unconstitutional purpose to burden or to benefit a particular group, ${ }^{42}$ but the purpose still exists. The rationality test under consideration here does not itself contain standards for labeling certain purposes illegitimate; ${ }^{43}$ it merely requires a rational fit between purpose and statutory means.

39. 391 U.S. at 72.

40. See note 38 supra.

41. 391 U.S. at 80 (Harlan, J., dissenting).

42. See, e.g., cases cited note 4 supra.

43. Cf. Ely, supra note 6, at 1246; A. Bicket, The Least Daxgenous Braxcit 225 (1962). The possibility that the "tautological" purpose itself might be detcrmined to be impermissible by some independent standard is discussed pp. 138-41 in/ra. 
If all statutes are "tautologically" rational, how is it that the courts have struck down so many under the equal protection rationality test? Professor Ely has tentatively suggested that courts may have developed principled doctrines to restrict the range of acceptable goals for different types of legislation so that the rationality test is at least sometimes apposite. ${ }^{44}$ It will be argued below, however, that the courts have not developed such doctrines and that the rationality test is always inapposite. It will be suggested in section II that in every case in which the Court has construed a statutory goal in such a way that the statutory classification could be found to be not rationally related to the legislative purpose, it would have been equally possible to define the purpose so that the statute could have been found ration. al. It will be suggested in section III that the courts have sometimes admitted the (necessary) rationality of statutes but have used various doctrines and devices to avoid the conclusion that the statute is therefore constitutional under the rationality test of the Equal Protection Clause.

\section{Irrationality and the Definition of Purpose}

The various methods by which courts have been able to define a statute's purpose such that the classification used in the statute is inappropriate to its purpose ${ }^{45}$ are interrelated and usually achieve the same result-non-consideration of the purpose suggested by the plain terms of the statute. Nevertheless, for purposes of illustration these methods have been divided here into three groupings: (A) ignoring a purpose, (B) stating the purpose as a unit rather than as a mix of policies, and $(C)$ manipulating the level of abstraction at which the purpose is defined.

\section{A. Ignoring a Purpose}

On occasion courts have attempted to show that a statute is not rationally related to any purpose by listing several purposes to which

44. Ely, supra note 6, at 1224-28. For example, Ely argues that a court might restrict its attention to the goal of promoting public safety in evaluating a safety regulation that also was designed to aid farmers economically. With the statute's purposes thits restricted the rationality test could be meaningfully applied. Ely, supra note 6 , at 1226 . 27, 1237-39. But see pp. 142-46 infra.

45. There may in fact be some valid reason for a court to so frame the statitory purpose in any particular case. The point throughout this discussion is not to debatc which goal was the "real" goal but to argue that at a minimum the goal suggested by the statutory terms should also be examined and accounted for. If it is, the rationality requirement will be met and the court need go no further with respect to that requirement. 
the statute is not rationally related. Such enumeration, however, does not establish a priori that there is not some other purpose to which the statute is rationally related.

In Gulf, Colorado \& Santa Fe Ry. v. Ellis, ${ }^{\text {to }}$ for example, the Supreme Court struck down a statute ${ }^{4 i}$ that permitted successful tort claimants to recover attorneys' fees, if the suit had been brought against a railroad corporation. The Court started from the proposition that a legislative classification must rest upon some difference "which bears a reasonable and just relation to the act . . ." 48 The Court then suggested several possible purposes and resultant classifications for such a statute. Its goal might have been to ensure that tortfeasors would compensate their victims, but then the statute should have applied against all tortfeasors. ${ }^{49}$ Its goal might have been to place a higher duty to pay such obligations on corporations because the government grants corporations special privileges, but then the appropriate category would have been all corporate tortfeasors..$^{50}$ The goal might have been to extract a higher duty from quasi-public corporations, but then the appropriate category would have been all quasi-public corporate tortfeasors. ${ }^{51}$ Having demonstrated its ability to speculate about purposes that might be appropriate to statutes employing broader classifications, it is somewhat astonishing that the Court was unable to imagine a purpose that corresponded to the narrower category of "railroad corporations." The possibility that railroad corporations had a tendency to resist payment of petty claims and that this was the limited evil at which the legislation was aimed was not, however, lost to the dissenters. ${ }^{52}$

The inability of a court to find an appropriate legislative purpose is no less dubious when it merely posits one purpose for a statute, rather than listing multiple possibilities as the Court did in Gulf $R y$. For example, in Smith v. Cahoon ${ }^{53}$ the Court considered a statute that

\footnotetext{
46. 165 U.S. 150 (1897). fees .... not to exceed $\$ 10$... [ [sic]. at 151-52.

48. 165 U.S. at 155.

49. Id. at 156-57.

50. Id. at 157 .

51. Id.

52. Id. at 167 (Gray dissenting).

53. 283 U.S. 553 (1931).
}

47. Section 1... [A]ny person in this State having a valid bona fide claim for personal services rendered or labor done or for damages . . a against any railway corporation operating a railroad in this Statc, and the amount of stuch cham does not exceed $\$ 50$, may . . institute suit thereon in the proper court; and if he shall finally establish his claim, ... he shall be cntitled to recover the full amount of such claim and all costs of suit, and in addition thereto all reasonable attorney 's

Sayles Supplement to Texas Civil Statute, p. 768, art. 4260a (1889), cited in 165 U.S 
required a bond of all motored carriers except those transporting agricultural goods. Positing that the purpose of such bonds is the public safety and arguing that agricultural carriers had no characteristics that made their exemption relevant to public safety, the Court struck down the law. If the Court had formulated the purpose of the statute by examining its terms, the purpose might have been phrased as follows:

The purpose is to insure public safety to the extent that no additional burden need be placed on the agriculture industry.

It has been suggested that the Court in Smith ignored one of the obvious purposes of the statute because of an implicit rule that when there is consensus concerning the usual aims of certain types of legislation, that consensus will define a statute's purpose to the exclusion of other possible purposes. ${ }^{54}$ Whether or not it is a sensible use of the Equal Protection Clause to force the legislature to employ only orthodox means for the achievement of certain ends, ${ }^{65}$ it is certainly clear that to state that the only purpose of the statute was public safety is a fiction. The very terms of the statute make it plain that one "goal the legislators had in mind" 56 was to favor the agriculture industry. ${ }^{.7}$ Another example of an ignored purpose occurred in Harper $v$. Virginia Board of Elections ${ }^{58}$ when the Court struck down a poll tax statute on the grounds that, inter alia, "wealth, like race, creed, or color, is not germane to one's ability to participate intelligently in the electoral process." 50 The possibility that a poll tax might be enacted for reasons other than to establish qualifications for voting was denied by the court:

[W] must remember that the interest of the State, when it comes to voting, is limited to the power to fix qualifications. ${ }^{.0}$

Even if it is conceded that one purpose of a poll tax is to reduce the number of poor voters, it is a fiction (accomplished by the fiat of defining what the state's interest in voting can be) to state that the only

54. Ely, supra note 6, at 1225-26.

55. For example, should it be unconstitutional for the legislature to attempt to aid farmers by excluding them from the requirements of a safety bond mercly becausc such statutes normally are not used as subsidies?

56. Ely, supra note 6, at 1225 .

57. Of course, such a purpose might be thought impermissible. See pp. 140.41 infra.

58. 383 U.S. 663 (1966).

59. Id. at 668. The rationale of this contention is ambiguous. See A. BrCKEt, 'TItE Surreme Court and the Idea of Progress 59-61 (1970).

60. 383 U.S. at $668(1966)$. 
purpose of a poll tax is to reduce the number of poor voters. In a prior case the Supreme Court itself acknowledged that a tax burdening the right to vote is not necessarily the equivalent of an absolute qualification for voting:

Payment as a prerequisite [to voting] is not required [by this statute] for the purpose of denying or abridging the privilege of voting. ${ }^{61}$

The Court could see various purposes for a poll tax besides fixing an arbitrary qualification for voting in $1937^{\circ 2}$ but could not see them in 1966. ${ }^{63}$ The point here is not to argue which purpose was the more important or to imply that a majority of the legislators who established the poll tax might not have intended that the tax exclude the poor from voting. The point is simply that in order to invalidate the poll tax under the equal protection rationality test, the Court conveniently overlooked a statutory purpose that it had previously found was rationally related to the statute's classifications.

\section{B. Framing the Purpose as a Unitary Value}

Courts, of course, are aware that legislation is normally contrived to achieve a mix of purposes, with compromise and bargaining among the legislators determining the trade-offs among the competing purposes. In Carmichael v. Southern Coal \& Coke Co., ${ }^{64}$ for example, a tax levied to create an unemployment compensation fund was upheld even though the tax was not imposed on employers who had less than eight employees. The Court pointed out that the legislation was not aimed merely at providing unemployment compensation but also was intended to do so at low cost and with administrative convenience. ${ }^{.5}$ Thus the statutory exemption might have been prompted by a legislative desire to avoid the administrative costs of collecting from numerous small employers.

But in other, comparable cases the Court has refrained from recognizing that a statute can be aimed at achieving a mix of goals. In F.S.

61. Breedlove v. Suttles, 302 U.S. 277,282 (1937).

62. One purpose of the poll tax acknowledged by the Breedlove Court was the raising of money for educational purposes. Id. at 282.

63. Both the statute in Harper and the statute in Breedlove v. Sutules, 302 US. 277 (1937), made payment of the tax a prerequisite of voting, and Justice Douglas made no effort to distinguish them in this respect. Harper v. Virginia Bd. of Elections, 383 U.S. 663, 669 (1966).

64. 301 U.S. 495 (1937).

65. Id. at 513 . 
Royster Guano Co. v. Virginia, ${ }^{66}$ for example, the Court considered a statute that taxed income earned by a corporation from corporate activities both within and without the state but exempted income earned by a domestic corporation whose income arose entirely from out-ofstate activities. Such a statute is rather clearly intended to encourage corporations that do no business in the state to incorporate within it so that the state can derive the benefits of incorporation without any of the corresponding burdens. ${ }^{67}$ But the Court assumed that the tax scheme was contrived to tax corporations in proportion to the amount of protection the state afforded the corporation as it carried on its business within the boundaries of the state. Given this purpose, the class of exempted corporations could be found to be too narrow since the foreign -earnings of corporations that also earned income within the state were not exempted. Although there is no renson to suppose that the purpose formulated by the Court was not $a$ purpose of the statute, the very terms of the statute make it fictional to treat that purpose as the only purpose of the legislation.

Similarly, when the goals of the wrongful death statute considered in Levy $v$. Louisiana ${ }^{68}$ were considered in isolation-either the compensation of children for the wrongful death of their mother or increasing the number of formalized marital relationships-it was plausible to argue that the statute did not achieve its purpose, for some children were never compensated and the causal link between withholding such compensation and increasing the number of formalized relationships is by no means clear. ${ }^{60}$ But the full purpose of the statute was a combination of these purposes. The relative mildness and potential ineffectiveness of the incentives indicate that one goal of the legislation was not to guarantee a certain number of formalized marriages but rather to encourage formalization of relationships in general by fostering a general belief among the citizens that the government does not approve of illegitimate children. And, since illegitimate children were not to be compensated, the other statutory goal was not to compensate all children at whatever social cost that might involve but only to the extent that governmental policies would not somehow condone the failure to formalize a marriage. Failure to treat the purpose of the wrongful death statute as a mix of competing policies

66. 253 U.S. 412 (1920).

67. This point was made by the F.S. Royster dissenters. Id. at 418 (Justices Brandeis and Holmes).

68. See pp. 130-31 supra.

69. Cf. Glona v. American Guarantee \& Liability Co., 391 U.S. 73, 75 (1968). 
does make it easier to find "irrationalities" in the statute but only because the statutory terms are then tested against a simplified statutory goal. Similarly, in Baird the Massachusetts statute regulating the distribution of contraceptives could be found rational only if tested against a legislative purpose reflecting a complex public policy. ${ }^{\text {To }}$

\section{G. Manipulation of Level of Abstraction}

Just as it is always possible for a court to ignore a legislative purpose $^{i x}$ or to simplify it in such a way that the statute cannot meet the rationality requirement, ${ }^{72}$ it is always possible for a court to define the evil or the good at which legislation is aimed so as to make the statutory classifications too broad or too narrow for achieving the purpose thus defined. In Gulf $R y$., for instance, the statute-which gave a right to attorneys' fees to successful tort claimants who had sued a railroad-was rather obviously aimed at encouraging the payment of tort claims. ${ }^{73}$ But whether the statute was rationally adapted to achieve its purpose depended on how wide a class of tortfeasors it was designed to affect. The evils the statute might have been aimed at can be stated in the following order of descending generality:

(1) to decrease the likelihood that any tortfeasor will escape his obligation to repay his victim,

(2) to decrease the likelihood that any corporation might abuse the privilege of existence afforded it by the state by escaping its obligation to repay tort victims,

(3) to decrease the likelihood that any business corporation will abuse the privilege of carrying on business activities that the state affords it by escaping its obligation to repay tort victims,

(4) to decrease the likelihood that any quasi-public, commercial corporation will abuse its special function by escaping its obligation to repay tort victims,

(5) to decrease the likelihood that railroad corporations, which have a tendency to resist the demands of tort claimants, will escape their obligation to repay their victims.

The Court's conclusion that the statutory classification was underinclusive followed inevitably from the level of generality at which it defined the evil at which the statute was thought to be aimed. The Court argued that the statute might have been intended to deal with

70. See pp. 127-28 supra.

71. See pp. 132-35 supra.

72. See pp. 135-37 supra.

73. See p. 133 supra. 
problems as broad as (1) and as narrow as (4)..$^{74}$ Of course, if the Court had acknowledged the fifth purpose, a conclusion that the classification was rationally related to the purpose would have followed. The terms of the statute plainly suggest that the Court had defined statutory purposes too broadly. ${ }^{75}$

In Baird the Court emphasized that the Massachusetts legislature could not reasonably have intended to deter premarital sexual behavior because the exceptions to the statute did permit unmarried persons to obtain contraceptives-for example, when the contraceptives were to be utilized for the prevention of disease. ${ }^{76}$ Obviously, the statutory exceptions make the statute "irrational" only if it is assumed that the goal of the legislation was to deter all premarital sexual activity. The statute's terms show that the legislation was not designed to deter all premarital sex but to "discourage" 17 such behavior at least to the extent that the statute's disincentives would not add to a different problem (the spread of venereal disease). ${ }^{78}$ The conclusion that the statute was irrational as to the objective of discouraging premarital sex followed inevitably from the Court's decision to judge the statute against a goal far broader than the goal that the statute, on its face, was designed to accomplish.

\section{Admission and Avoidance}

In the last section it was suggested that it is always possible for a court to define a statute's purpose such that the statute will not meet the rationality requirement. The difficulty with such definitions of purpose, it was argued, is that because they necessarily do not reflect the statutory terms fully, there is always an element of artificiality about a "purpose" thus defined. If a statute's terms are fully reflected in the court's definition of its purpose, however, it is inevitable that the statute will fulfill the rationality requirement. To avoid this dilemma, courts have sometimes acknowledged that the statute is rationally related to a purpose but have still denied that the statute therefore meets the equal protection rationality requirement. The two grounds for this denial to be discussed here are: (A) that the statute is rationally related to an impermissible goal, or (B) that the statute is not

74. 165 U.S. at $156-59$.

75. See note 47 supra.

76. See notes 21-23 supra.

77. The plurality did acknowledge that this was the appropriate word but sometimes switched to "deter." See 405 U.S. at 448 (1972).

78. See notes 16-17 supra. 
rationally related to a mandatory goal. The effect of using either of these arguments is to avoid the significance of the fact that the legislation is rationally related to some legislative purpose.

\section{A. Impermissible Goals}

When a statutory goal has been declared impermissible but is not in violation of any explicit constitutional provisions, courts have sometimes left the reasons for labeling a purpose "impermissible" unarticulated and unexplained. This was true, for example, in Mayflower Farms, Inc. v. Ten Eyck. ${ }^{79}$ In that case the Court struck down a statute that permitted milk dealers who had been in business prior to a fixed date to sell milk at a price lower than that permitted newcomers in the field. The favoritism inherent in the legislation was obvious to the Court:

The challenged provision is ... not a regulation of a business or an activity in the interest of . . the public, but an attempt to give an economic advantage to those engaged in a given business at an arbitrary date as against all those who enter the industry after that date. ${ }^{80}$

The assumption of the Court, obviously, was that the favoring of one economic group cannot be "in the interest of . . . the public." Since that purpose was impermissible, the fact that the legislation was rationally contrived to achieve that goal stood, by the Court's analysis, only to condemn it.

A close examination of one of the traits that distinguished the two classes of milk dealers, however, convinced the dissenter, Justice Cardozo, that the statute did have a legitimate purpose:

But the position of men in business at the beginning of the change was very different from those who might go into business afterwards. Those already there would lose something more than an opportunity for a choice between one business and another. They would lose capital already ventured; they would lose experience already bought .... [A] newcomer could not pretend that he was exposed to those afflictions. ${ }^{81}$

Both majority and dissenters agreed, then, that the purpose of the statute was to keep newcomers out of the field. ${ }^{82}$ The majority described

79. 297 U.S. 266 (1936).

80. Id. at 274.

81. Id. at 277 .

82. See id. at 273 . 
the statutory goal as disadvantaging newcomers, while the dissent described it as protecting the capital investment of established dealers. Neither emphasis is more speculative than the other because both formulations merely state that the statutory burden or benefit will fall on those possessing the traits that define the statutory classes..$^{83} \mathrm{It}$ should have been plain to the Court that one of the traits defining the established group was that they had something to lose by competition just as it was clear to the Court that one of the traits defining the newcomers was that they had something to gain.

If one formulation was an accurate statement of the statutory purpose, the other formulation also had to be accurate because the two goals were reciprocal: In part, it was by disadvantaging the newcomers that the legislation sought to protect the established dealers. Under either phraseology the statute is rationally related to a purpose.

Mayflower Farms demonstrates, then, one difficulty with avoiding the conclusion of constitutionality by the device of labeling one of the goals impermissible: the statutory terms may indicate two (or more) purposes, one arguably impermissible and one arguably permissible but either capable of making the statutory classification tautologically rational. To strike down such a statute involves, therefore, an implicit but far-reaching principle: a statute rationally related in equal degree to several purposes is unconstitutional if only one of those purposes is impermissible.

It might be objected, however, that the goals in Mayflower Farms are unusual and that the one objective set of social consequences reflected by a statute's terms may involve no permissible goals. It might be, for example, that the Mayflower Farms court was willing to hold that neither disadvantaging the newcomers nor protecting the capital investment of the established dealers was a permissible goal. Nevertheless, that single set of social consequences will be related to a more remote set of consequences, and at some point along the range of causality there should be some permissible goal for any conceivable statute. Consider, for example, these two wordings of the purpose behind the statute considered in Smith $v$. Cahoon: ${ }^{84}$

(I) The purpose of the exemption for agricultural carriers is to put more money in the pockets of farmers.

(2) The purpose of the agricultural exemption is to benefit the American economy by strengthening the agricultural sector.

83. The majority implied, however, that to seek further for a rationally related goal would be to "conjure." $1 d$. at 274 .

84. See pp. 133-34 supra. 
The second phrasing of legislative purpose is as much a reflection of the statute's terms as is the first, because the method by which the agricultural sector is to be strengthened is by putting more money in the pockets of farmers. Absent some theory of social causality that holds that the agricultural sector cannot be strengthened by putting money in the pockets of farmers or that the American economy cannot be benefited by strengthening the agricultural sector, the second wording is as valid a purpose of the legislation as is the first. ${ }^{85}$ Although the narrower wording implies favoritism and therefore might be treated as impermissible, the broader wording is surely a permissible purpose.

To the extent that any statute can be found to be rationally related to some benign goal, the voiding of any statute because it is also rationally related to an impermissible goal cannot be described as an implementation of the traditional equal protection rationality requirement. In such cases the requirement that the statute be rationally related to a legitimate objective has been met. Thus, the statute can only be voided in spite of the rationality requirement. This result might be explained by reference either to (1) some analysis of legislative motivation, or to (2) some implicit or explicit balancing process.

\section{Motivation}

The Court in Mayflower Farms might have had some way of knowing that the legislators "really" intended to disadvantage newcomers to the milk distribution field, not to protect existing investments; and the Court in Smith 0 . Cahoon might have had some way of knowing that the legislators' "real" purpose was to line the pockets of farmers without regard for the welfare of the general economy. Since in each case both the "real," intended goal and the unintended goal are suggested by the same statutory terms and involve the same social or economic consequences, the Court's special knowledge could not have come merely from examining the statute or its consequences. The Court would have had to know or to conjecture what prompted a majority of the legislators to enact the legislation, using something like the motive test proposed by Professor Ely. ${ }^{80}$

A major difficulty with defining "real purpose" as legislative motivation is, as Ely fully acknowledges, ${ }^{87}$ that the motivations behind

85. See generally Ely, supra note 6, at 1235 el seq.

86. In discretionary choice situations, the question upon which the triggering of review must turn is whether the decision maker-or a majority of the decision makers-employed an unconstitutional criterion of selection in making the choice .....

Ely, supra note 6, at $126 \%$.

87. Id, at $1217-21,1267$. 
voting for a statute are as varied as all the possible consequences of the statute's enactment. For example, one piece of legislation might have all the following consequences: its enactment salves the conscience of one legislator; it brings bribe money to another; it directly benefits the constituency of a third; some of its indirect consequences will benefit the constituency of a fourth, and other of the indirect consequences will benefit the constituency of a fifth, and so on. How is a court to determine which consequences a majority of the legislators had in mind when each legislator might have had several motivations and no majority had the same set of motivations? ${ }^{88}$ It would seem that, at best, the determination of legislative motivation would be a tangled empirical problem, necessarily involving the simplification of complex motivational patterns concerning equally complex anticipated social and personal consequences.

Nevertheless, Ely argues that in certain circumstances a judicial inquiry into legislative motivation is both necessary and potentially principled. ${ }^{89}$ In general terms, his argument is that when a statutory goal is "non-rational" in that, inter alia, the goal is too vague for a meaningful measure of whether the statutory means are rationally related to $\mathrm{it}^{\mathrm{90}}$ and when it can be demonstrated "that an unconstitutional criterion of selection was employed," 01 the statute should be voided notwithstanding the possibility that a majority of legislators also had permissible motivations. ${ }^{92}$ At this level of generality, Ely's arguments by their terms do not purport to implement the rationality requirement, since on the face of his analysis, motivation is a relevant consideration only when the rationality test is inapposite..$^{03}{ }^{\circ}$

The assumption that an inquiry into legislative motivation is sometimes "irrelevant" 94 because the rationality test is apposite conflicts with previous discussion which has suggested that the rationality requirement is never apposite. ${ }^{05}$ The difference arises because Professor Ely narrowly defines "non-rational" goals. He describes two types of non-rational goals that are relevant here-subjective goals and the "umbrella" goal of the general welfare. ${ }^{00}$ Subjective goals, like the promo.

88. See id. at 1212-14, 1217-21, 1267.

89. Id. at 1262 and passim.

90. Id. at $1237 \cdot 41$.

91. Id. at 1267 .

92. Id. at 1267-68 (on "triggering:" review), $1272-73$ (on voiding the statute).

93. See id. at 1272-73 and passim.

94. "If, however, motivation is confined to its proper role.. . the existence of a legitimate defense will render motivation irrelevant." Id. at 1279 . See also 1275.81.

95. See pp. 128-38 supra.

96. Id. at 1237. 
tion of good taste or the expression of retribution against a criminal act, depend fundamentally on individual judgment and values so that, Ely argues, an objective measure of the degree to which a goal has been fulfilled is impossible. ${ }^{97}$ The umbrella goal exists in "discretionary choice" situations ${ }^{98}$ where "the Court is unprepared to restrict an area's class of acceptable goals to anything more precise than the promotion of the general welfare." 99 For example, in areas like taxation, because "the courts stand ready to credit as acceptable any goal the political branches regard as conducive to the general welfare," 100 legislative goals are more usefully described as being the general welfare, which like good taste, is too vague a goal for the rationality test. ${ }^{101}$

If what characterizes these "non-rational" goals is the lack of objective criteria for determining whether the statutory purpose is being achieved, it is difficult to see why most legislative goals are not also "non-rational." Even an apparently objective goal, like the promotion of public safety, ${ }^{102}$ can be shown to be too vague for objective measurement. Consider, for instance, the safety regulation that was upheld in Railway Express Agency, Inc. v. New York. ${ }^{103}$ In that case, the Court upheld a traffic regulation which banned advertising from the sides of motor vehicles but exempted from this requirement those vehicles which advertised the business of the owner of the vehicle. The Court treated "public safety" as the goal of the regulation in question and was able to uphold the statute only by the somewhat tortured reasoning that the legislature "may well have concluded" that the self-promoting advertisements were less of a threat to public safety than were advertisements for hire. ${ }^{104}$

Surely "public safety" is too large a goal and competing public purposes are too many for any statute to have as its single purpose the promotion of safety. Safety has its costs and any statute that stops short of abolishing all physical risks, at whatever cost, incorporates other purposes which further expenditures for safety would otherwise frustrate. ${ }^{105}$ Accordingly, the regulation considered in Railway Express

\footnotetext{
97. Id. at $1241,1244-45$.

98. See id. at 1246-48.

99. Id. at 1247.

100. Id. at 1248 (emphasis removed).

101. Id.

102. Safety has been selected as an example because Professor Ely used it as an example of a goal for which the rationality test could be apposite. See id. at 1237-38.

103. 336 U.S. 106, 107-08 (1949).

104. Id. at 110 .

105. See G. Calabresi, The Cost of Acciberts 17-20, 31 (student edition, 1970): Calabresi, The Decision for Accidents: An Approach to Nonfault Allocation of Costs, 78 Harv. L. Rev. 713, 716-21 (1965).
} 
was obviously not designed to abolish all the risks of driving in New York City nor even to remove all the distracting signs from that city. Its purpose was more limited and might be formulated as follows:

The purpose is to promote public safety slightly by reducing the number of distractions on the sides of moving vehicles to the extent this is feasible without jeopardizing the economic well-being of those merchants who advertise on their own trucks. ${ }^{100}$

Thus, even such seemingly straightforward statutes can involve goals that reflect an accommodation of various purposes which are determined by subtle or blatant policy trade-offs.

When the complexity of the policy trade-offs are not acknowledged in the formulation of legislative purpose, the simplified goal appears to be objective. Thus, the Court in Railway Express felt compelled to assert that perhaps the legislature knew somehow that the ownership of a truck had some causal relationship to the number of accidents caused by the advertisements on its side. But when the legislative goal is seen as a set of policy trade-offs, an objective measure of its fulfillment is not so easy. The mix of competing social policies that are represented by the legislation perhaps does point to some net public good that the legislation is designed to achieve. But how can a court determine whether the changes created by the Railway Express statute represent the net public good that the legislation was originally designed to effect? To resolve this issue a court would have to face the following kinds of questions. How much distraction and how many accidents are caused by permitting the self-promotional advertising? How significant to the community are these costs? How much better off are those merchants who benefit from the advertising? How significant is this benefit to the community? By what standard are these changes in the community's welfare to be weighed against each other? Is the result the "net public good" that the statute was designed to achieve? In short, statutes that have ostensibly objective goals like public safety in reality have as their goal some vague, legislatively-defined increment in the public welfare that is no more subject to objective measurement than are goals like promoting good taste.

106. Professor Bickel was surely wrong to suggest that "the discrimination between display advertising in Times Square and truck advertising was wholly irrational." A. BiCKEL, supra note 6 , at 225 (emphasis added). If public safety had been the only goal that the statute had been designed to achieve, Professor Bickel would have becin correct; yet such single-minded definition of statutory purpose ignores the complexity of the policies reflected in the statute's terms. 
However, because it is the function of statutes to render concrete legislative judgments concerning such "non-rational" matters as what constitutes good taste or how the demands of safety should be accommodated to other public purposes, the statutory terms themselves do provide an objective measuring standard for purposes of the equal protection rationality requirement. Thus, to use a variation of Professor Ely's example, ${ }^{107}$ a statute prohibiting the wearing of sneakers on the grounds that sneakers are in bad taste can be evaluated accord. ing to its own terms. The purpose of the statute is to promote good taste, which is defined by the statute as the absence of sneakers; only sneaker wearers are given incentives not to wear sneakers under the statute; therefore, the statute is rationally related to its purpose. Similarly, if the purpose of the safety regulation in Railway Express is said to include the goal of providing some financial protection for certain truck drivers because these owners were exempted from the advertising prohibition by the terms of the statute, it is not surprising that the terms of the statute should be found to be reasonably designed to achieve this set of policies.

Ely's analysis of the proper role for motivation-inquiry in discretionary choice situations can, therefore, be seen as an effort to circumvent such hollow judgments of the rationality test. Ely argues, in effect, that despite the fact that the rationality requirement can be fulfilled as regards some permissible purpose (or "subgoal") in discretionary choice situations, legislation should nevertheless be struck down when it can be shown that a majority of the legislators intended that the statute achieve an unconstitutional purpose. ${ }^{108}$ The justifica-

107. Ely, supra note 6, at 1239 .

108. Professor Ely argues:

Of course an inference of illegitimate motivation will often be rendered impossible by the likelihood that the choice in issue was in fact the product only of a simple judgment of what promotes the general welfare. I suspect, for example, that the vast majority of farmers are white. But the likelihood that in granting farmers subsidies most congressmen were genuinely moved to a feeling that a secure agricultural economy contributes to a healthy America would, barring evidence of which I am not aware, compel the rejection of an inference that such prosisions were racially motivated . . . . If, however, it could be convincingly demonstrated that a majority of the legislators granted farmers subsidies for racial reasons, the fact that they may also have believed that a strong farming economy promotes the general welfare should not preclude judicial review of the choice.

$I d$. at 1268 . Having justified judicial review, he goes on to arguc:

[O]n the rare occasion when an inference of unconstitutional motivation an responsibly be drawn in the face of such a "subgoal rationalization," the possibility of rational justification still need not be considered; on such an occasion, the choice simply must fall .... [T] he fact that explanations on the subgoal lerel ... must be treated as nonrational in light of the amorphous nature of the ultimate acceptable goal ... suggests with equal force that such explanations cannot be regarded as "rational" for purposes of alternative justification cither. If the demand for a rational choice/goal relation is never apposite, it an never be satisfied.

Id. at 1272-73. 
tion for Ely's rule cannot be that in some circumstances the rationality requirement is meaningless, for it is as meaningful in reference to what Professor Ely calls "non-rational" goals as it is in reference to any goal. The justification is that the rationality requirement is always meaningless because it can always be satisfied. ${ }^{100}$ Seen in this light, Ely's analysis provides a rationale for avoiding this empty conclusion.

\section{Balancing}

Perhaps in Mayflower Farms or in Smith v. Cahoon the Court did understand that the statutes involved had both permissible and impermissible goals and that the fact that some or all of the legislators were motivated by the possibility of reaching impermissible goals could not erase the plain terms of the statute suggesting permissible goals. If this assumption is made, the outcomes of those cases might be explained as the result of judicial balancing of the relative importance of the permissible and impermissible goals. For example, the Mayflower Farms decision might be explained on the principle that the harm done to the free enterprise system outweighed the benefit accorded the protected milk dealers. A rule that, when two goals are equally related to the statutory terms, an impermissible goal is more salient than a permissible goal could explain why in the court's view such a statute is "evil." It does not explain why the statute does not fulfill the rationality requirement. ${ }^{110}$ Nevertheless, this balancing process can be found in two equal protection doctrines-strict scrutiny and impermissible means.

Strict Scrutiny. In certain "strict scrutiny" cases, decisions have been fairly explicitly based on the court's balancing of the relative importance of the statute's permissible and impermissible purposes. The Court has, for example, indicated that the importance to the government of reducing expenditures will not justify a statute that is also rationally contrived to distribute burdens according to "invidious

109. Professor Ely's argument for resort to motivation analyses was prompted by the same consideration:

In discretionary choice situations, the question upon which the triggering of re. view must turn is whether the decision maker. . . cmployed an unconstitutional criterion of selection in making the choice in issuc. The fact that he or they also may have been influenced by a simple judgment of taste or a desire to pro. mote the general welfare, should be deemed irrelevant. . . .

Unless this conclusion is accepted, no choice made in a "discretionary" area will be reviewable ....

Id. at 1267 (emphasis added).

110. See A. BickeL, supra note 6 , at 225 . 
classifications."111 Similarly, the Court has indicated that when the achievement of a statutory goal entails abridging a "fundamental interest," the statute will be struck down if that goal does not involve a "compelling governmental interest." 112 This set of doctrines enables courts to strike down statutes that are admittedly related rationally to a permissible goal on the grounds that the value of this goal is outweighed by the value of the impermissible goal to which the statute is also related. The rationality requirement is irrelevant to this kind of balancing process since the rationality of the statute as to all goals is conceded, and the decisions turn on a balancing of the importance of the different goals.

Another aspect of the strict scrutiny doctrine is the requirement that, if one of the statutory goals is the burdening of a fundamental interest or a suspect category, the statute must not only further a compelling governmental interest but also its classificatory scheme must be necessary for accomplishing that interest. ${ }^{113}$ This requirement is generally taken to mean that the accuracy of the legislative classification will be examined with greater care. ${ }^{114}$ There is no reason to suppose, however, that a more careful examination of the statute's classifications should lead to the conclusion that the statute is not rational. A strict scrutiny of the statute should, indeed, suggest classificatory inaccuracies, but, as argued in section $I$, the identification of these inaccuracies should only suggest a more refined definition of the statute's purpose. ${ }^{115}$

It might be argued that the rationality requirement, or at least a stringent rationality requirement, can be meaningful when combined with a determination that one or more statutory goals are impermissible. The intuitive appeal of this argument lies in the possibility that if one or more of the statutory goals can be eliminated as impermissible, it should be possible to find classificatory inaccuracies with regard to those goals which remain. The Supreme Court used such an approach in Shapiro $v$. Thompson, ${ }^{110}$ in which state welfare residency requirements were struck down. The Court first determined that the goal of discouraging the poor from changing residence in order to obtain higher welfare benefits was an impermissible goal because it

111. Graham v. Richardson, 403 U.S. 365,376 (1971).

112. Shapiro v. Thompson, 394 U.S. 618, 638 (1969).

113. See note 5 supra.

114. "[S]trict scrutiny of the classification ... is essential . . . Skinner v. OHa. homa, 316 U.S. 595, 541 (1942) (emphasis added).

115. See pp. 128-32 supra.

116. 394 U.S. 618 (1969). 
was an unconstitutional abridgment of the right to travel. ${ }^{117}$ The Court found "no occasion to ascribe the source of this right to travel interstate to a particular constitutional provision," but did insist that the right was fundamental under the Constitution. ${ }^{118}$ The Court then acknowledged that its determination that one statutory goal was impermissible did not necessarily mean that the statute was not rationally related to other, permissible goals. Four alternative purposes were considered: (1) facilitating budget planning, (2) providing an objective test of residency, (3) minimizing the chance of a recipient fraudulently receiving checks from two jurisdictions, and (4) encouraging enrly entry into the labor market. ${ }^{110}$ The Court dismissed these goals partly on the grounds that they were not compelling governmental interests, ${ }^{120}$ and insofar as this was the basis of the Court's decision, the holding turned on a balancing of the importance of goals rather than on an implementation of the rationality requirement. ${ }^{121}$ But the Court went further in an apparent effort to apply the rationality requirement. Having eliminated the statute's obvious purpose (providing disincentives to migration) as impermissible, the Court determined that, as to the other goals, the statute's provisions were not rational. ${ }^{22}$

Like the statute in Mayflower Farms, however, the welfare residency requirement has a permissible goal that is reciprocally related to the impermissible goal. The goal of encouraging early entry into the labor market is reciprocally related to the goal of discouraging an inward migration of welfare recipients. There can be little doubt that a yearlong delay before receiving welfare benefits is rationally related to encouraging entry into the labor market. It is precisely this same threat of delay and the concomitant pressure to find work at any personal cost that is the disincentive to migration. Given this causal relationship, it is not clear why the Court concedes "that the one-year waiting period device is well suited to discourage the influx of poor families in need of assistance," ${ }^{123}$ but denies the rationality of the statute for encouraging early entry into the labor market. ${ }^{124}$

The Court's first phrasing of the goal of encouraging early entry into the labor force was:

117. Id. at 631 .

118. Id. at $630-31$.

119. Id. at 634 .

120. Id. at 638 .

121. That is, the court held in effect that the importance of the right to travel outweighed the administrative advantages of the residency requirement to the government.

122. Id. at $635-38$.

123. Id. at 629 .

124. Id. at 637-38. 
(1) The goal is "encouraging new residents to join the labor force promptly."125

But when holding the statute not rationally related to this goal, the Court rephrased the statute's purpose as follows:

(2) The goal is "to encourage employment . . ."120

With the goal thus reworded, the Court found the statute's classifications under-inclusive because the statute would not function to encourage long-time residents of the state to seek employment. And so in a case combining the strict scrutiny standard with a determination that one statutory goal was impermissible, the Court was able to find the statute not rational only by the device of defining the degree of evil at which the statute was aimed so broadly that the finding of classificatory imprecision, and hence statutory irrationality, necessarily followed. ${ }^{127}$ The statutory terms, ${ }^{128}$ of course, suggest a narrower purpose to which the statute's classifications were rationally related:

(3) The goal is to provide an incentive to find jobs for those who encounter extraordinary obstacles in the way of finding work (created by the dislocation of moving interstate).

The point here is not to criticize the result in Shapiro; it is merely to argue that a combination of the strict scrutiny doctrine with a determination that one statutory purpose is impermissible still does not make the rationality requirement useful. However, if the holding of the Court that the residency requirement was not rationally related to any of its objectives is disregarded as an artifice resulting from the Court's method of formulating the statute's purpose, the holding in Shapiro can be viewed as resting only on a balancing process. ${ }^{120}$ Thus the rationality requirement was not implemented but was again circumvented. ${ }^{130}$

Impermissible Means. It is sometimes suggested that, although a

125. Id.

126. Id.

127. But see pp. 137-38 supra.

128. CoNn. GEN. STAT. REv. \$ 17-2d (1965 Supp.) [now 17-2C (Supp. 1968)] provided: When any person comes into this state without visible means of support for the immediate future and applied for aid to dependent children .. . or general as. sistance ... within one year from his arrival, such person shall be eligible only for temporary aid or care until arrangements are made for his return ....

An exception was made for those who had a bona fide job offer. $i$ Coss. Wenfane Manual, C II, § 219.1-219.2, cited in 394 U.S. at $622 \mathrm{n} 2$.

129. See p. 148 supra.

130. See p. 146 supra. 
legitimate legislative purpose exists and although the statutory classifications are rationally related to that purpose, the means chosen are inconsistent with the Equal Protection Clause. In Reed v. Reed, , $^{131}$ for example, a unanimous Court struck down an Idaho law that established a preference for males when two or more individuals (who otherwise qualified under the statute) sought to be appointed the administrator of the same estate. ${ }^{132}$ The Court began by invoking the traditional rationality test-the means chosen could not be "wholly unrelated to the objective."133 The Court then admitted that the statute did achieve one purpose-it eliminated the need for some hearings at which the relative qualifications of competing applicants would be weighed. Having found the statute rationally related to a permissible purpose, the Court did not then validate the statute. Instead, it asserted:

The crucial question, however, is whether the statute advances that objective in a manner consistent with the command of the Equal Protection Clause. ${ }^{134}$

The Court answered its question in the negative, having found that the statute's presumption against women amounted to arbitrary discrimination. ${ }^{135}$ The difficulty with this reasoning is that the only definition offered by the Court of "arbitrary discrimination" was the "some rationality" test, ${ }^{136}$ which requires only that the classification be precise with regard to a legitimate purpose. Since the statute was admittedly rationally related to a permissible purpose, in what sense was its discrimination arbitrary?

The only answer supplied by the Court was that there was something arbitrary in the manner by which the objective was to be accomplished. ${ }^{137}$ The manner in which the permissible objective was

131. 404 U.S. 71 (1971).

132. Section 15.312, IDAHo CODE ANN. (1947), provided:

[O]f several persons claiming and equally entitled to administer, males must be

preferred to females ....

133. 404 U.S. at 75-76.

134. Id. at 76 (emphasis added).

135. Id.

136. The Court held that:

To give a mandatory preference to members of either sex . . . is to make the very kind of arbitrary legislative choice forbidden by the Equal Protection Clause ..... Id. at 76. But earlier the Court stated that

The Court has consistently recognized that the Fourteenth Amendinent does not deny to State the power to treat different classes of persons in different ways . . . . [But] a classification "must be reasonable, not arbitrary, and must rest upon some ground of difference having a fair and substantial relation to the object of the legislation ...."

Id. at 75-76 [citations omitted].

137. 404 U.S. at 76 . 
to be accomplished was by disadvantaging women in competing for positions as administrators of estates. Assuming that women are generally as capable of acting as administrators of decedents' estates as are men, the statute is not well designed for picking the most competent administrators. With respect to this purpose, the disadvantaging of women could easily be viewed as axbitrary under the rationality requirement. To hold that statutory means are impermissible because they are arbitrary is apparently, then, no more than to hold that the statute is not rationally related to some of its purposes. But the rationality requirement does not require that the classificatory distinction be rationally related to all possible legislative purposes. ${ }^{338}$ The Reed holding, therefore, cannot be explained on the basis of the traditional rationality requirement.

An alternative explanation of Reed is that the Court determined that the state's interest in judicial efficiency was less important than the interest of women in equal treatment with respect to the purpose of choosing qualified administrators of decedents' estates. The doctrinal basis of the decision is thus a disguised balancing test. The statute did not fall because it could not be shown to be rationally related to a permissible purpose but because the Court determined that the interest of women in equal opportunity outweighed a legitimate objective of the statute.

\section{B. Mandatory Goals}

All the admission and avoidance devices described in (A) above have a similar drawback. To the extent that they attempt to implement the rationality requirement, they rest on the questionable assumption that if a statute can be shown to be rationally related to an impermissible goal, the statute does not fulfill the rationality requirement. There is another admission and avoidance device-the assigning of a mandatory goal-that does not involve this difficulty.

If a court is ready to assert that any legislation in a certain area must pursue a certain goal or goals, a requirement of rationality can be used to determine whether the statute under consideration does in fact pursue that goal. Because the goal is independently mandated by the Court without reference to the legislatively determined statutory terms, it is not certain that the terms will reflect the mandated purpose. The fact that the statute may be (almost certainly is) rationally related to other permissible goals is irrelevant because to be constitu-

138. See pp. 139-4l supra. 
tional the statute must be rationally related to the mandated goal.

The reapportionment cases are an example of a field where the Court has explicitly mandated a goal for all legislation. The Court has recognized that reapportionment is an area where the possible legislative purposes are "complex and many-faceted." 130 But whatever purposes a reapportionment statute might be contrived to accomplish, the Court has mandated that all reapportionment plans must pursue at least one basic purpose:

The achieving of fair and effective representation for all citizens is ... the basic aim of legislative apportionment. ${ }^{140}$

In determining that the goals of reapportionment must include the goal of fair representation for individuals, ${ }^{141}$ the Court has made it clear that the source of the mandate is the Court's functional analysis of the requisites of democracy:

As long as ours is a representative form of government, and our legislatures are those instruments of government elected directly by and directly representative of the people, the right to elect legislators in a free and unimpaired fashion is a bedrock of our political system. ${ }^{142}$

In a later passage the Court made it clear that the goal of fair representation is an imperative one:

The basic principle of representative government remains, and must remain . . . the weight of a citizen's vote cannot be made to depend on where he lives. ${ }^{143}$

The Southern school desegregation cases are another example of an area where the courts have established a mandatory goal. Courts have required that whatever the other objectives of public educational policies in the South, they must have the objective of eliminating segrega-

139. Reynolds v. Sims, 377 U.S. 533, 566 (1964).

140. Id. at 565-66.

141. See Whitcomb v. Chavis, 403 U.S. 124, 141 (1971); Lucas v. Forty-fourth Gencral Assembly of Colorado, 377 U.S. 703, 736 (1964). The general goal of fair representation is most often expressed in the form of a sub-goal: requiring legislative districts to be apportioned according to population (one person-one vote). See Davis v. Mann, 377 U.S. 678, 690 (1964), Maryland Comm. for Fair Representation v. James, 377 U.S. 656, 674 (1964); Gray v. Sanders, 372 U.S. 368, 381 (1963).

142. Reynolds v. Sims, 377 U.S. 533,562 (1964).

143. Id. at 567 (emphasis added). 
tion in public schools. ${ }^{1 * 4}$ This mandatory goal was apparently originally deduced from a socio-political theory stressing the prime importance of education as a function of government ${ }^{145}$ and a socio-psychological theory regarding the inherent inequality of state-segregated schools. ${ }^{146}$

Utilization of mandatory goals as adjudicatory standards requires three prerequisites: there must be (I) some generally accepted theorysocial, political, legal, etc.-from which the court can credibly deduce the mandatory goal; this goal must be (2) definable in terms of a required burden or benefit; and the goal must (3) define the precise class to whom the benefit must be extended or on whom the burden must be placed. In the area of legislative apportionment, the goal was definable in terms of a benefit (the right to influence the outcome of elections by one vote) and in terms of the class on whom the benefit must be conferred (all eligible voters). In the desegregation cases the goal was defined as a benefit (the right to full educational opportunities) which was to be extended to the class of all citizens, regardless of race.

When a court is able to supply an independent goal that defines both the statutory burden or benefit and the statutory classification, $a$ rationality test can be used to invalidate legislation. Such invalidation need not rely on the assumption that if a statute is rationally related to an impermissible goal, it is not related to a permissible goal. Instead, the assumption behind the invalidation is that the goal supplied by the social or political theory is so important that the rational relationship of a statute to a permissible goal is not sufficient to outweigh the lack of a rational relationship to the mandated goal. In essence the mandated goal overbalances all other goals, permissible or impermissible.

Courts generally have not decided cases involving mandatory goals under the rubric of the equal protection rationality test. The point

144. [T] The obligation of every school district is to tcrminate dual [segregatcd] school systems at once and to operate now and hereafter only unitary schools. Alexander v. Holmes County Board of Education, 396 U.S. 19, 20 (1969). Accord Swamn v. Charlotte-Mecklenburg Bd. of Educ., 402 U.S. 1, 15 (197I); Green V. County Sehool Bd., 391 U.S. 430, 438-39, 142 (1968). See Griffin v. County School Bd., 37 U.S. 218 , 234 (1964).

145. Today, education is perhaps the most important function of State and local governments. Compulsory school attendance laws and the great expenditures for education both demonstrate our recognition of the importance of education to our democratic society . . . . It is the very foundation of good citizenship.

Brown v. Bd. of Educ., 347 U.S. 483,493 (1954).

146. See id. at 493-95. For an argument that sophisticated theorizing is unnecessary to find state-segregated schools in violation of Fourtcenth Amendment Equal Protection standards, see Black, Jr., The Lawfulness of the Segregation Decisions, 69 YALE L.J. 421 (1960). 
of the discussion here is to suggest that this has been a wise choice. Although the device of mandating a goal does involve the use of a rationality standard, it cannot implement the traditional rationality require. ment because it is, once again, a balancing process that determines the outcome.

\section{Conclusion}

Courts do not in fact use the rationality requirement to strike down statutes, because it is impossible to do so. Instead, courts sometimes ignore the clear import of a statute's terms to formulate a fictional statutory goal to which the terms are not rationally related. Or courts sometimes determine that a statutory goal is impermissible; but because legislative objectives are multifaceted, the finding of one impermissible goal does not mean that the rationality requirement-which requires merely a rational relationship to a permissible goal-cannot still be met. Therefore, courts sometimes question the legislators' motivation, balance the relative merits of competing legislative objectives, or assign mandatory goals. Even if such efforts are convincing, they only explain why the statute is unconstitutional despite the fact that it satisfies the rationality "test."

Because the disputes that arise under the rubric of the Equal Protection Clause have to do with the relative merits of competing public policies, ${ }^{14 \pi}$ judicial decisions obscure the central issues in such cases to the extent that they are based on discussions of a statute's rationality. The nature of the conflict between the political values at stake as well as the underlying bases of judicial reasoning would be made more explicit if the competing public policies were weighed outright without diversionary discussions regarding a statute's rationality. Of course, it is an open question how aggressively the Equal Protection Clause should be used. ${ }^{148}$ But however actively it is used in the future, the process of forthright constitutional adjudication would be well served if courts would recognize that discussion of a statute's rationality is a meaningless and confusing exercise.

147. See pp. 146-49 supra. Cf. A. Bickel, supra note 6, at 225.26.

148. See, e.g., A. Bickel, The Surreme Court and tie Ides of Proghess (1970); Dienes, To Feed the Hungry: Judicial Retrenchment in Welfare Adjudication, 58 CaL1F. L. REv. 555 (1970); Ely, Legislative and Administrative Motivation in Constitulional Law, 79 Yale L.J. 1205 (1970); Kurland, Egalitarianism and the Warren Court, 68 Mich. L. Rev. 629 (1970); Michelman, On Protecting the Poor Through the Fourteenth Amendment, 83 Harv. L. Rev. 7 (1969); Tussman and tenBroek, The Equal Protection of the Laws, 37 Calif. L. Rev. 341 (1949); Wechsler, Toward Neutral Principles of Constitt. tional Law, 73 Harv. L. Rev. I (1959); Wright, Professor Bickel, the Scholarly Tradition and the Supreme Court, 84 HARv. L. REv. 769 ((1971); Note, Developments in the LawEqual Protection, 82 HaRv. L. REv. 1065 (1969). 